\title{
BIG FOOT ART SITE, CANIA GORGE: SITE REPORT
}

\author{
CATHERINE WESTCOTT, IAN LILLEY, SEAN ULM, CHRIS CLARKSON AND \\ DEBORAH BRIAN \\ Aboriginal and Torres Strait Islander Studies Unit, University of Queensland, \\ Brisbane, Queensland, 4072, Australia
}

\begin{abstract}
This site report presents a description of archaeological investigations undertaken at Big Foot Art Site, a large rockshelter and art site located at Cania Gorge, eastern Central Queensland. Field and laboratory methods are outlined and results presented. Excavation revealed evidence for occupation spanning from before 7,700 cal BP up to at least $300 \mathrm{cal} \mathrm{BP}$, with a significant peak in stone artefact discard between c.4,200-3,200 cal BP. Results are compared to analyses undertaken in the adjacent Central Queensland Highlands.
\end{abstract}

\section{Introduction}

This report details preliminary results of two seasons of archaeological excavation conducted at Big Foot Art Site in January and September-October 1996. Excavations were undertaken as part of the on-going Gooreng Gooreng Cultural Heritage Project (see Lilley and Ulm 1995, this volume). This paper presents a site description, preliminary rock art description and census, stratigraphy, chronology, field methods, laboratory procedures and preliminary results of analysis.

\section{Site Location and Description}

Big Foot Art Site is registered as Queensland State Site Number JE:A07. The site is so-named because it is located near a natural feature and tourist attraction known as 'Big Foot' and because its walls exhibit a number of painted motifs. It is a large, northeastfacing sandstone shelter on the edge of Cania Gorge National Park, approximately $20 \mathrm{~km}$ north-northwest of Monto and about $120 \mathrm{~km}$ from the coast (Latitude: 24 ${ }^{\circ} 43^{\prime} 32^{\prime \prime}$; Longitude: $150^{\circ} 59^{\prime} 32^{\prime \prime}$; Easting: 296906; Northing: 7263930). The site is at the base of a dissected sandstone escarpment on the western side of Cedar Creek (Figures 1, 3-4). It has a floor area of approximately $20 \mathrm{~m}^{2}$ within the dripline, dipping slightly towards the front of the shelter. From about $3 \mathrm{~m}$ in front of the dripline, a talus slope drops away sharply to the creek flats below (Figure 2).

The shelter is approximately $200 \mathrm{~m}$ from the confluence of Cedar Creek and Three Moon Creek, the main waterway draining the Cania Gorge area, bordering extensive alluvial flats vegetated by open woodland. Cedar Creek has ephemeral rock pools but does not flow all year round. During field investigations in July 1997, permanent springs were located feeding Three Moon Creek near Contact Cave (Figure 1). There may be other springs, as permanent waterholes exist approximately $500 \mathrm{~m}$ upstream from Big Foot Art Site. The pre-European hydrology of the region is poorly understood. A large dam (Lake Cania) built upstream of the main gorge area has dramatically altered local waterflow patterns.

The site is one of a number of occupied rockshelters bordering alluvial creek flats at the southern end of the gorge (Figure 1). Roof Fall Cave is located approximately $80 \mathrm{~m}$ south along the escarpment and the Big Foot Boulder excavation (see below) was undertaken towards the base of the steep talus slope immediately below Big Foot Art Site. The site was originally recorded in 1991 by J. Pratt and G.A. Miller, who noted painted red and yellow motifs but made no comment regarding archaeological deposits in the shelter.

In the January 1996 field season, a single $50 \mathrm{~cm} \mathrm{x}$ $50 \mathrm{~cm}$ test pit, 15 , was excavated in the rockshelter to a maximum depth of $76 \mathrm{~cm}$ before encountering impenetrable roof fall. This small sample was augmented by a further two $50 \mathrm{~cm} \times 50 \mathrm{~cm}$ test excavations, G6 and G7, dug to bedrock near the original pit in the September-October 1996 field season (Figures 2, 5). After observing significant numbers of stone artefacts on the surface of the talus slope immediately below the shelter entrance, a $50 \mathrm{~cm}$ $x 50 \mathrm{~cm}$ pit was excavated close to the base of the talus slope to determine whether any subsurface cultural material existed in this area. This excavation, designated 'Big Foot Boulder', revealed virtually no cultural material. It will not be considered further here. Westcott's (1997) preliminary analysis of all cultural materials and a technological analysis of the stone artefacts from pit 15 provide the bulk of the data referred to in the following report.

\section{Rock Art}

Rock art is visible on the side and back walls of the shelter, occurring most frequently towards the back. The art assemblage consists of paintings only; there are no engravings or stencils. Table 1 gives a description of the paintings. 
Table 1. Preliminary description of rock art at Big Foot Art Site.

\begin{tabular}{|c|c|c|c|c|c|c|c|c|}
\hline & \multicolumn{3}{|c|}{ Figurative } & \multicolumn{3}{|c|}{ Non-Figurative } & \multirow{2}{*}{$\frac{\text { Other }}{\text { Unidentified }}$} & \multirow[b]{2}{*}{ Total } \\
\hline & Anthropomorph & Zoomorph & $\begin{array}{l}\text { Bird } \\
\text { Track }\end{array}$ & Trident & $\begin{array}{l}\text { Line (or set } \\
\text { of lines) }\end{array}$ & $\begin{array}{l}\text { Bar (or } \\
\text { set of bars) }\end{array}$ & & \\
\hline Red & $? 1$ & 8 & 21 & 3 & 12 & 3 & 2 & 50 \\
\hline Yellow & - & 2 & 3 & - & 3 & - & - & 8 \\
\hline Orange & - & - & - & 1 & 2 & 1 & 1 & 5 \\
\hline White & - & - & 1 & - & 1 & - & - & 2 \\
\hline Orange/Red & - & - & 1 & - & - & 1 & - & 2 \\
\hline Total & 1 & 10 & 26 & 4 & 18 & 5 & 3 & 67 \\
\hline
\end{tabular}

In addition to the motifs described here, there are many smears or patches of pigment that could not be interpreted as having any identifiable form, some of which may have been the result of natural mineral staining. These patches are not recorded in Table 1. The entire assemblage is monochromatic, executed in solid colour with no discernible outlines. Most of the paintings are red $(74.6 \%)$, some are yellow (11.9\%) and the remainder are executed in white and orange. Where colours are recorded as mixed, it is because one colour is superimposed over another, or one colour is weathering away to reveal another colour underneath. The colours are often faded and patchy, owing to exfoliation of the sandstone surface.

There is one possible anthropomorph, although that is uncertain owing to the extent of exfoliation affecting the painting. The largest zoomorphs and non-figurative designs measure up to $135 \mathrm{~cm}$ in their maximum dimension, although most are smaller than $60 \mathrm{~cm}$.

\section{Excavation Aims and Methods}

As one of only two recorded sites in Cania Gorge prior to the investigations of the Gooreng Gooreng Cultural Heritage Project, Big Foot Art Site was inspected during initial surveys of the area in July 1995. This work indicated that the site had considerable research potential. Subsequent investigations sought to assess this potential further through test excavations. Of particular interest were questions concerning the nature, extent and antiquity of subsurface cultural remains and the age of the rock art.

Of all of the excavated cultural remains, the stone artefacts have the greatest potential to answer questions concerning patterns of site use through time, and to allow reflection on broader questions about Australian archaeology. Mulvaney's influential model of Australian stone assemblages was largely based on archaeological evidence from the nearby Central Queensland Highlands (Mulvaney 1975; Mulvaney and Joyce 1965). Cania Gorge is geographically adjacent to this area. Results from the on-going work at Cania Gorge will provide a test for aspects of Mulvaney's model, help determine how the model articulates with other regions, and at what level it may really be applicable beyond the Central Queensland Highlands.

All three $50 \mathrm{~cm} \times 50 \mathrm{~cm}$ test pits at Big Foot Art Site were oriented approximately northeast-southwest and dug in arbitrary $2-3 \mathrm{~cm}$ excavation units (XUs) within stratigraphic units (SUs), determined by changes in soil colour, composition or consistency. Elevations were recorded at the beginning and end of each excavation unit, using a local datum and a string line level. Sediments from each $X U$ were weighed in buckets on a tared spring balance and dry-sieved through $3 \mathrm{~mm}$ sieves before bagging and labelling. Material above $30 \mathrm{~mm}$ in maximum dimension was plotted in situ in three dimensions and bagged individually. Sediment samples (c.200g) were collected from each excavation unit. Squares G6 and G7 were excavated to bedrock at an average depth of $59 \mathrm{~cm}$ and $65 \mathrm{~cm}$ respectively (Figures 5-6). Sandstone bedrock was reached in Square I5 at $76 \mathrm{~cm}$ (Figure 7).

\section{Stratigraphy}

Squares $G 6$ and $G 7$

Squares G6 and G7 were excavated as adjacent $50 \mathrm{~cm}$ $\times 50 \mathrm{~cm}$ squares to create a $50 \mathrm{~cm} \times 1 \mathrm{~m}$ trench (Figure 2). Very few stone artefacts were recovered from SU6 which rested on bedrock. The upper SUs, including a hearth (SU3a), are clearly delineated but the changes between the lower SUs are gradational. The SUs are shown in the section drawing in Figure 6 and are described in Table 2. 


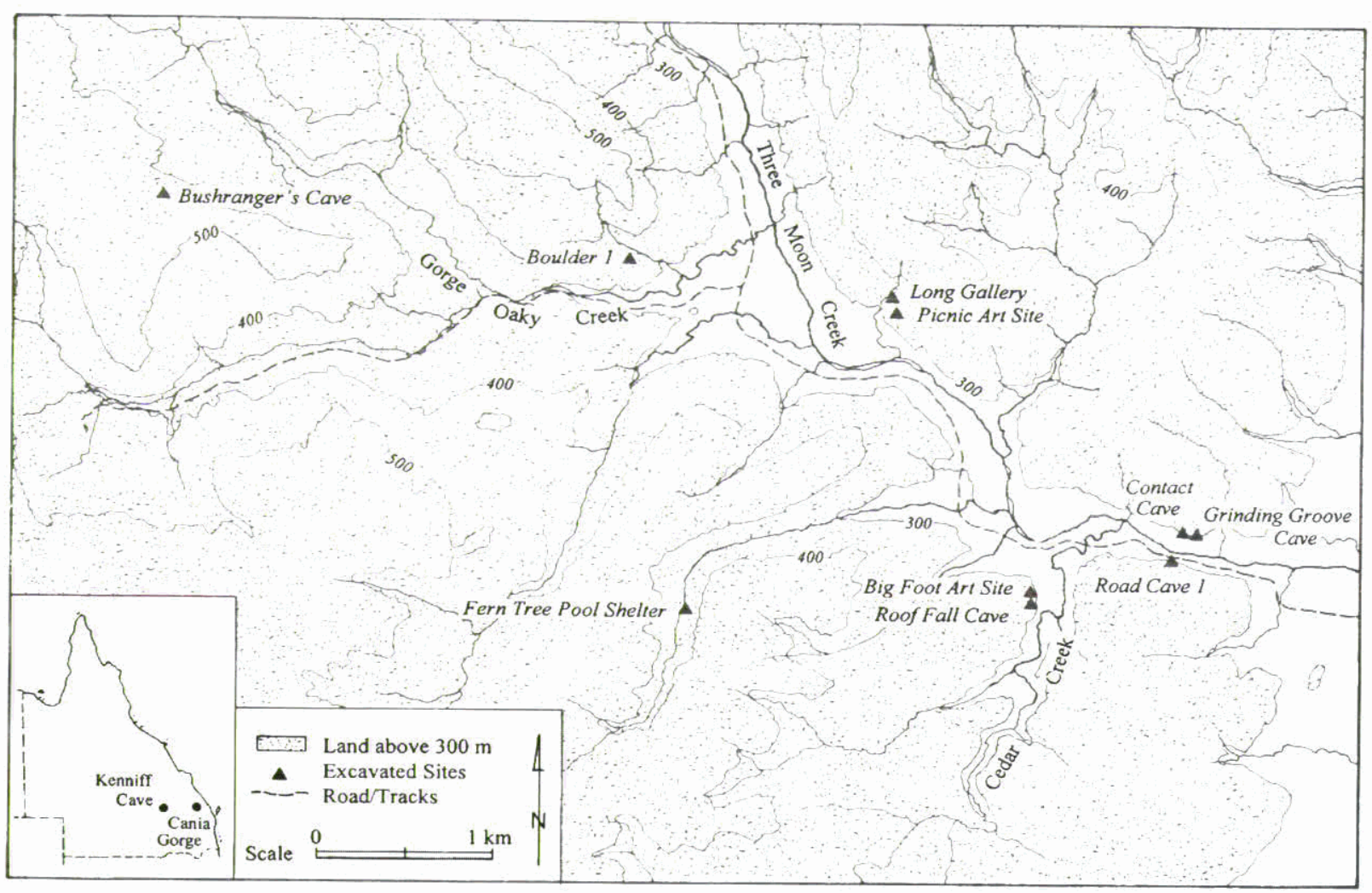

Figure 1. Southern Cania Gorge, showing excavated rockshelter sites.

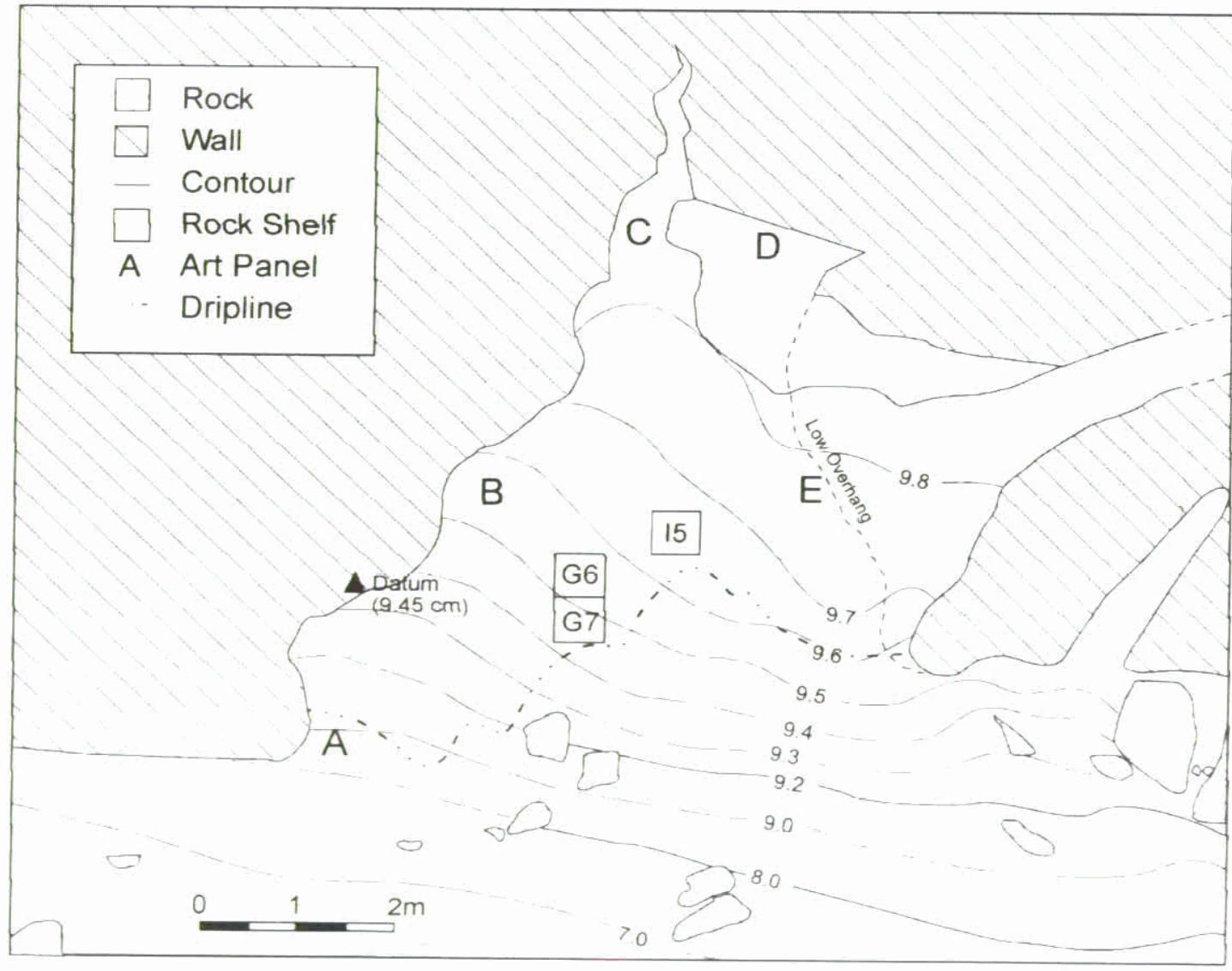

Figure 2. Plan of Big Foot Art Site. Letters refer to art panel designations. 


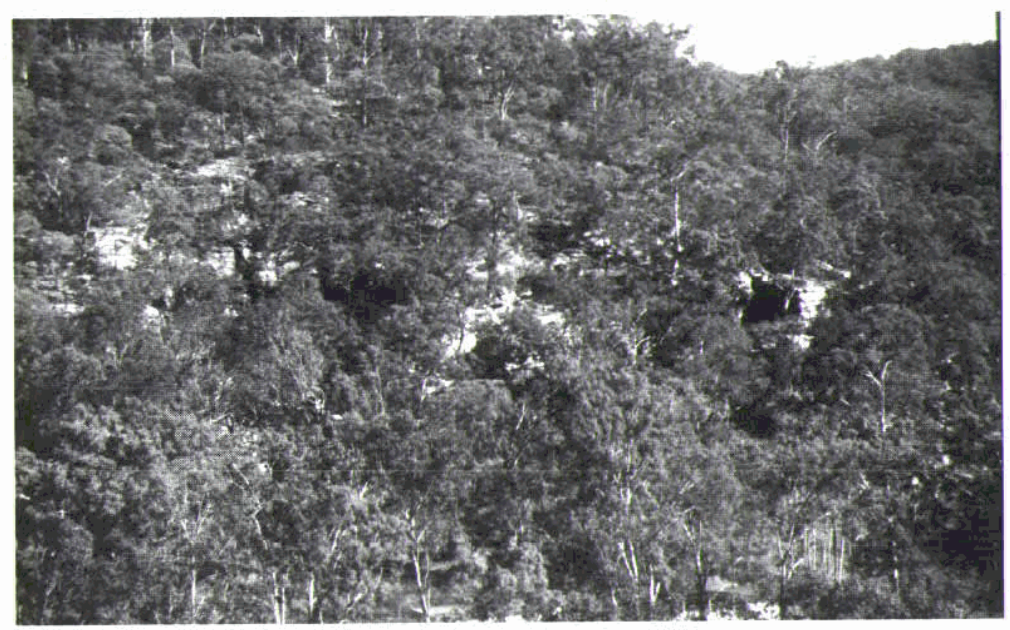

Figure 3. General location of Big Foot Art Site from the opposite escarpment, showing the shelter entrance in the centre of the frame (Photograph: S. Ulm).

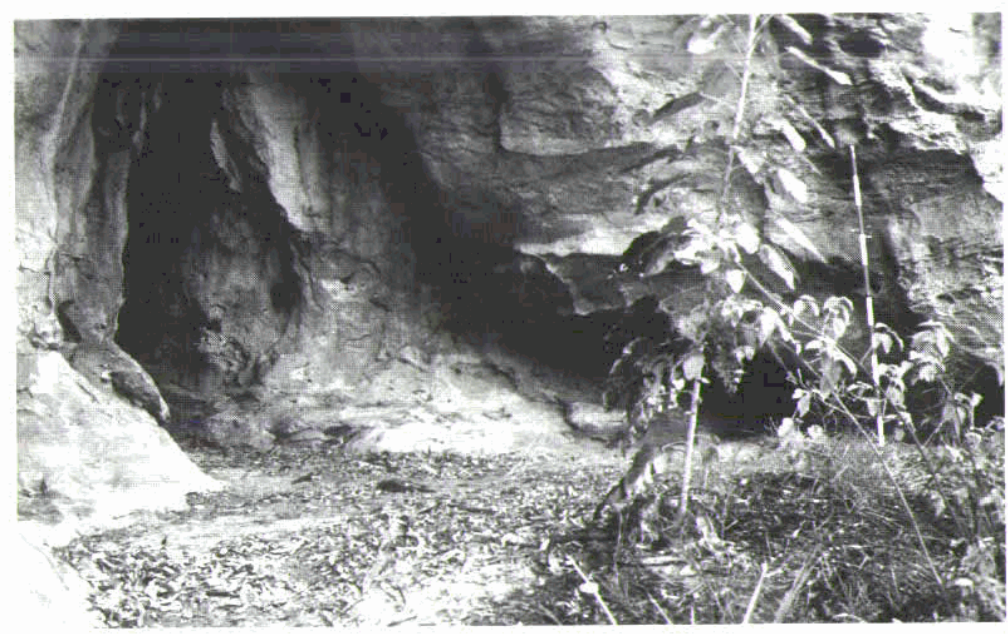

Figure 4. General view of the Big Foot Art Site shelter (Photograph: D. Brian).

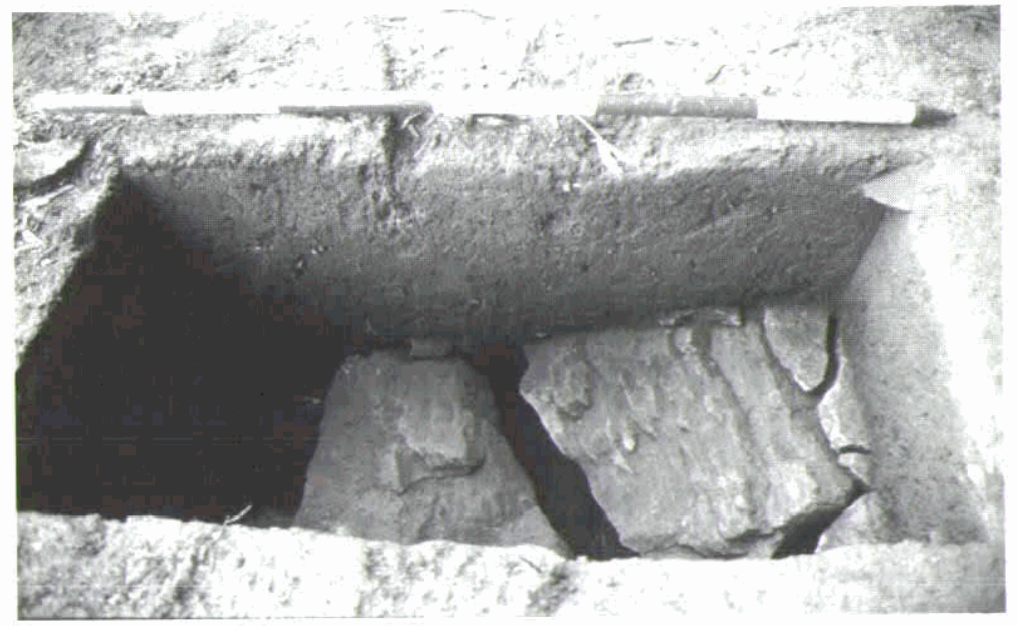

Figure 5. General view of Squares G6 and G7 at completion of excavation (Photograph: D. Brian). 


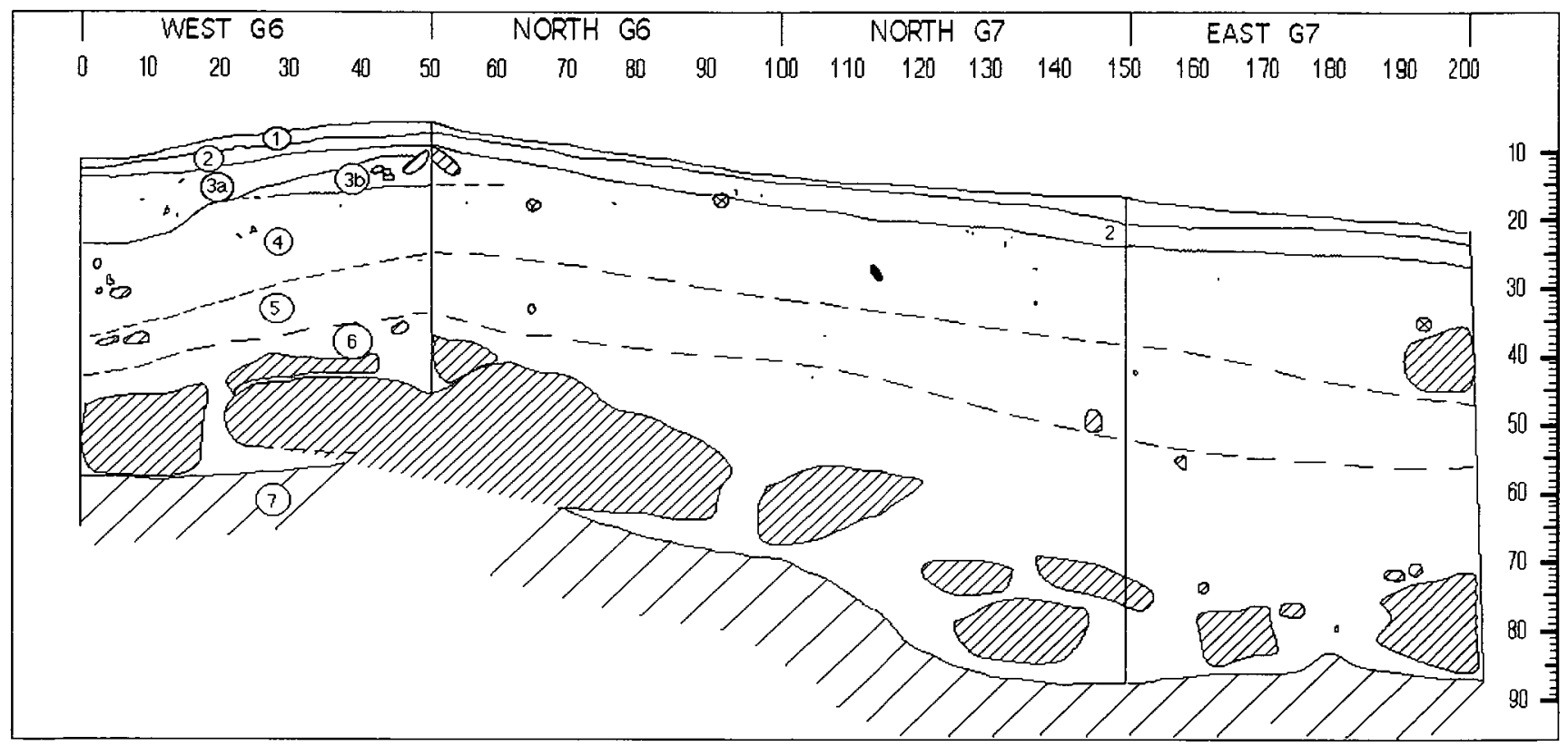

Figure 6. Section drawing of Squares G6 and G7. South section not shown.

Table 2. Description of stratigraphic units, Squares G6 and G7.

\begin{tabular}{|c|c|}
\hline SU & Description \\
\hline 1 & $\begin{array}{l}\text { Sediments consist of loosely consolidated, coarse sands, dry and light-grey in colour. } \\
\text { Sediments are ashy and contain numerous inclusions of charcoal, seeds, leaves, twigs, bark } \\
\text { and roots. }\end{array}$ \\
\hline 2 & $\begin{array}{l}\text { Sediments comprise compact, dry, grey, ashy sands. The structure is blocky and sub-angular } \\
\text { and peds are roughly } 10 \mathrm{~mm} \text {. Some organic matter is present and small pieces of charcoal and } \\
\text { rootlets are common. }\end{array}$ \\
\hline $3 a$ & $\begin{array}{l}\text { A compact, grey and white hearth layer which appears to be intrusive into the underlying SU4 } \\
\text { in the southwest corner of G6. This feature is restricted to the west and south sections of G6. } \\
\text { Large blocky pieces of charcoal are common as are stone artefacts and calcined bone. } \\
\text { Sediments are blocky and angular. Peds are roughly } 5 \mathrm{~mm} \text {. }\end{array}$ \\
\hline $3 b$ & $\begin{array}{l}\text { Light grey-brown, ashy sands. This appears to be the baked surface of the underlying SU4. } \\
\text { Sediments are loose and still dry, but moister than SU3a. }\end{array}$ \\
\hline 4 & $\begin{array}{l}\text { Dry, grey-brown, ashy sands. Charcoal is present but in smaller quantities than SU3a. Small } \\
\text { rootlets are common. Larger roots appear at the boundary between SU4 and SU5. The } \\
\text { structure is blocky and sub-angular. Peds are roughly } 10 \mathrm{~mm} \text {. }\end{array}$ \\
\hline 5 & $\begin{array}{l}\text { Sediments compact and light-brown in colour, containing numerous fragments of } \\
\text { disintegrating sandstone. The structure is sub-angular and blocky, with peds about } 10 \mathrm{~mm} \text { in } \\
\text { length. }\end{array}$ \\
\hline 6 & $\begin{array}{l}\text { Loose and relatively moist, dark-grey, ashy sands. Charcoal is abundant and small rootlets are } \\
\text { common. Large roots occur at the interface of SU5 and SU6. Larger ( }>75 \mathrm{~cm} \text { in maximum } \\
\text { dimension) pieces of disintegrating sandstone are common, particularly towards the base of } \\
\text { this SU. Structure is sub-angular and blocky, with peds about } 10 \mathrm{~mm} \text {. }\end{array}$ \\
\hline 7 & $\begin{array}{l}\text { Bedrock consisting of ridged, sloping sandstone, with few signs of regolith. One piece of } \\
\text { degraded flat regolith }(10 \mathrm{~cm} \text { wide } x 1 \mathrm{~cm} \text { thick) rests on the bedrock beneath the large block } \\
\text { of roof fall against the south wall, } 30 \mathrm{~cm} \text { from the west wall. Apart from this piece of regolith, } \\
\text { the surface is intact and there are no other signs of disintegration. }\end{array}$ \\
\hline
\end{tabular}




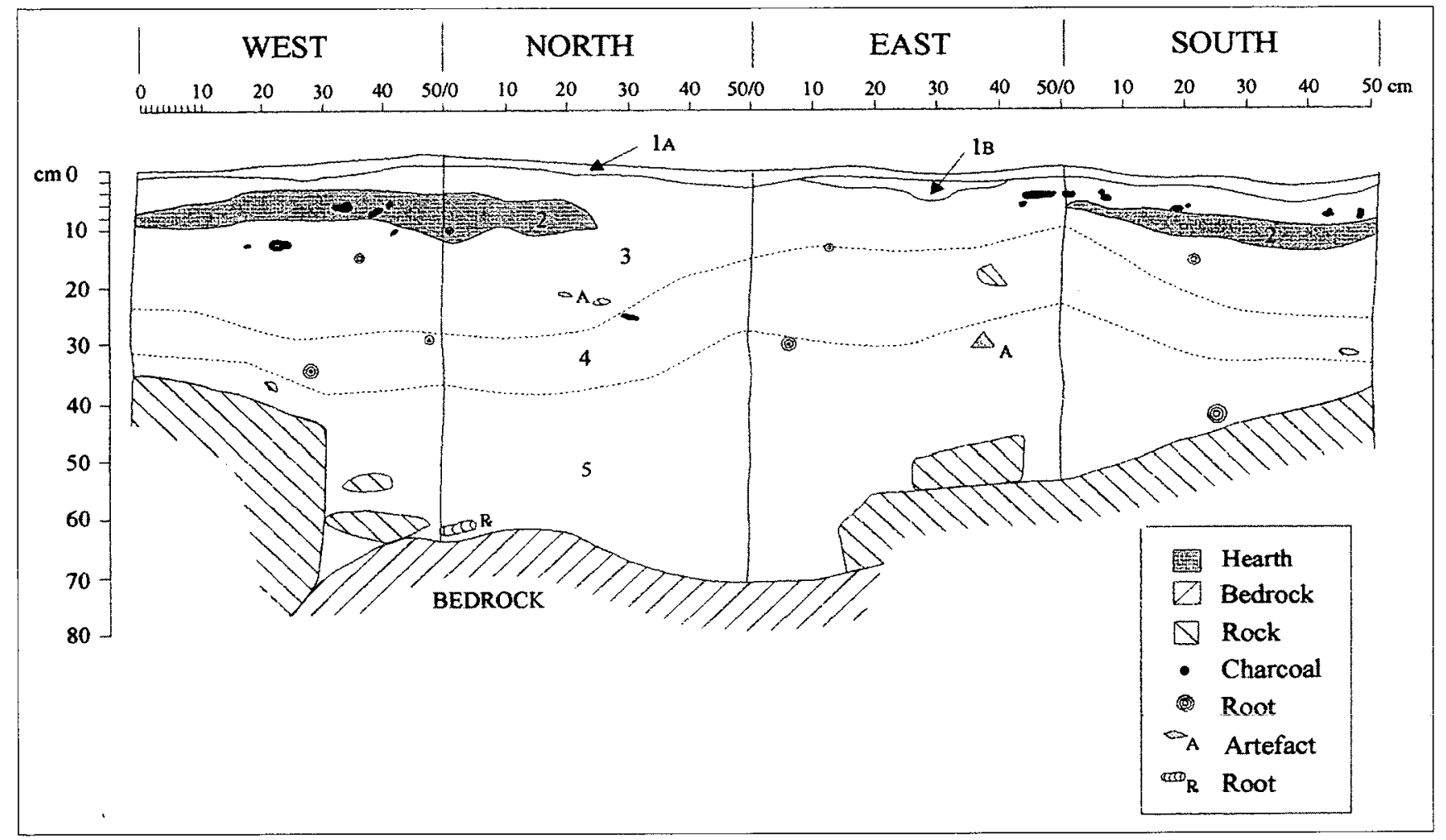

Figure 7. Section drawing of Square I5.

Table 3. Description of stratigraphic units, Square 15.

\begin{tabular}{|c|l|}
\hline SU & \multicolumn{1}{c|}{ Description } \\
\hline $1 \mathrm{a}$ & $\begin{array}{l}\text { Surface layer containing organic materials such as leaves, twigs, seeds and nuts. Fine, loose } \\
\text { sand with small pebbles and small pieces of charcoal. Light-grey in colour. }\end{array}$ \\
\hline $1 \mathrm{~b}$ & Compacted layer of quartz gravel. \\
\hline 2 & $\begin{array}{l}\text { Ashy layer, quite compact. Sediments are light-grey, mottled with yellow-white. Burnt bone } \\
\text { and blocky charcoal are present, as well as fine roots. }\end{array}$ \\
\hline 3 & $\begin{array}{l}\text { Ashy sediments mixed with sand. Grey in colour. Sediments are fairly compact but become } \\
\text { less consolidated towards the base of the unit. Burnt bone and charcoal occur throughout. }\end{array}$ \\
\hline 4 & $\begin{array}{l}\text { Damp, sandy, ashy layer. Sediments are similar to SU3 but darker and damper. Colour is grey- } \\
\text { brown. Small pieces of charcoal, large roots and artefacts are present. }\end{array}$ \\
\hline 5 & $\begin{array}{l}\text { Sandy sediments, moister than SU4. Dark-brown. Small pieces of ochre, artefacts, and small } \\
\text { and large pieces of charcoal are present. }\end{array}$ \\
\hline 6 & $\begin{array}{l}\text { Bedrock, consisting of large slabs of sandstone with little or no evidence of disintegration. } \\
\text { It dips towards the northeast of the pit. Two large pieces of roof fall overlie the bedrock in the } \\
\text { southeast corner and the western side of the square. }\end{array}$ \\
\hline
\end{tabular}


Table 4. Relationship between stratigraphic units and excavation units, Square I5.

\begin{tabular}{|l|l|}
\hline SU & \multicolumn{1}{|c|}{ XU } \\
\hline $1 \mathrm{a}$ & 1 \\
\hline $1 \mathrm{~b}$ & $4 \mathrm{~b}$ \\
\hline 2 & $5,6 \mathrm{a}, 6 \mathrm{~b}, 10,11 \mathrm{a}, 11 \mathrm{~b}$ \\
\hline 3 & $2,3,4 \mathrm{a}, 7,8,9,12 \mathrm{a}, 12 \mathrm{~b}, 13 \mathrm{a}, 14 \mathrm{a}, 15 \mathrm{a}, 16 \mathrm{a}, 17 \mathrm{a}, 18 \mathrm{a}, 19 \mathrm{a}, 20 \mathrm{a}$ \\
\hline 4 & $13 \mathrm{~b}(1), 13 \mathrm{~b}(2), 14 \mathrm{~b}, 15 \mathrm{~b}, 16 \mathrm{~b}, 17 \mathrm{~b}, 18 \mathrm{~b}, 19 \mathrm{~b}$ \\
\hline 5 & $20 \mathrm{~b}, 21,22 \mathrm{a}, 22 \mathrm{~b}, 23,24,25,26,27,28,29,30,31,32,33,34,35,36,37,38$ \\
\hline
\end{tabular}

\section{Square 15}

Six SUs have been identified at Square I5, including bedrock. They are shown in the section drawing in Figure 7, while the descriptions are given in Table 3. The changes between the stratigraphic units, with the exception of SU2, are gradational. SU2 has clear stratigraphic boundaries and is interpreted as a hearth or complex of hearths. However, SU1b is a small gutter, intruding from the eastern face of the square. There were no artefacts in SU1b and the unit appears to be the result of disturbance. The relationship of XUs to SUs is detailed in Table 4.

\section{Chronology}

Four radiocarbon dates have been obtained from charcoal samples from Square I5 (Table 5). No dates have yet been obtained from Squares G6, G7 or the Big Foot Boulder excavation. Conventional ${ }^{14} \mathrm{C}$ ages are corrected for ${ }^{13} \mathrm{C} /{ }^{12} \mathrm{C}$ fractionation and were calibrated using the CALIB (Version 3.0.3c) computer program (Stuiver and Reimer 1993), using the bi-decal atmospheric calibration curve based on the dataset of Stuiver and Pearson (1993) with no laboratory error multiplier. Forty years were subtracted before calibration to correct for ${ }^{14} \mathrm{C}$ variations between northern and southern hemispheres. The calibrated ages reported span the $2 \sigma$ calibrated age-range (Lilley et al. 1998:30).

Both the conventional ${ }^{14} \mathrm{C}$ ages and equivalent calibrated ages and their associated sample depths were used to plot the linear regression shown in Figure 8 . The central tendencies of the radiocarbon ages were used, as were the mid-points of the calibrated ages. The resulting age-depth curve shows a high correlation between age and depth for both the radiocarbon ages $\left(r^{2}=0.9927\right.$; not shown in Figure 8) and the calibrated ages $\left(r^{2}=0.9916\right)$.
Straight line regressions demonstrate the general age-depth relationship of a site, but they can only provide an average of depositional rates, masking potential variations in deposition (David and Chant 1995:377). Geomorphic processes should also be taken into account. Although detailed geomorphic investigations have not yet been undertaken at Big Foot Art Site, the excavators reported no evidence for lag deposits or hiatuses in deposition. Within these limitations, the strong correlation shown suggests a relatively continuous rate of sediment deposition from c. 8,000 cal BP until at least 300 cal BP. Relatively continuous, in this case, means "that neither the dates nor the stratigraphy give any indication of an obvious hiatus in occupation of sufficient length to be visible using these indicators" (Allen 1996b:165).

\section{Laboratory Procedures}

Excavation revealed a cultural assemblage dominated by flaked stone artefacts of diverse lithology, quantities of bone (burnt and unburnt), abundant charcoal, and small amounts of ochre. Details of cultural remains recovered from Square 15 are presented in Appendix A. Although Squares G6 and G7 have not been analysed, field observations suggest a similar gross assemblage composition and structure to that revealed in Square I5.

The material from Square I5 was sorted into the categories of artefactual stone, non-artefactual stone, charcoal, bone, organic material, insect remains, soil, shell, ochre and unknown. Each component from each $\mathrm{XU}$ was weighed, bagged and labelled with site identification, XU number and field specimen (FS) number. The stone artefacts were not washed, but were counted, and bagged individually to minimise the potential for cross-contamination of residues. 
Table 5. Radiocarbon dates, Square I5 (Lilley et al. 1998:30).

\begin{tabular}{|c|c|c|c|c|c|c|l|}
\hline Square & XU & $\begin{array}{c}\text { Depth } \\
(\mathbf{c m})\end{array}$ & Lab. No. & Sample & $\begin{array}{c}\text { Weight } \\
(\mathbf{g})\end{array}$ & ${ }^{14}$ C Age & Calibrated Age/s \\
\hline I5 & $4 \mathrm{a}$ & 5.0 & Wk-4880 & charcoal & 15.5 & $330 \pm 50$ & $474(306) 0^{*}$ \\
\hline I5 & $6 \mathrm{a}$ & 8.5 & Wk-4881 & charcoal & 9.0 & $590 \pm 50$ & $646(542) 506$ \\
\hline I5 & $20 \mathrm{~b}$ & 35.5 & Wk-4879 & charcoal & 11.1 & $4170 \pm 60$ & $4834(4802,4771,4609,4587,4574) 4442$ \\
\hline I5 & 36 & 66.5 & Wk-4638 & charcoal & 13.9 & $7040 \pm 70$ & $7923(7787) 7640$ \\
\hline
\end{tabular}

0* Represents a 'negative' or 'modern' age BP.

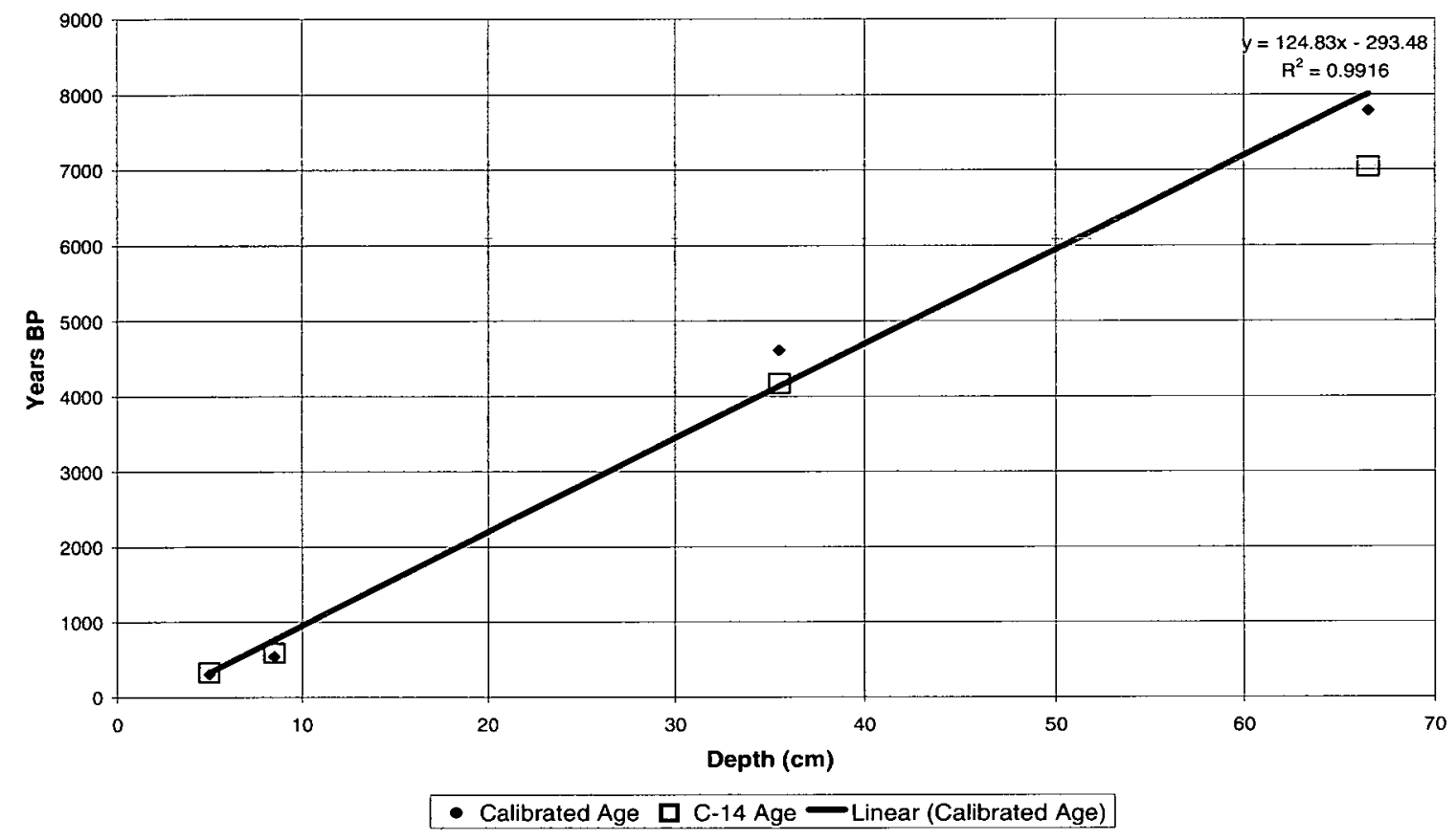

Figure 8. Linear regression of age-depth data, Square I5.

\section{Analytical Units}

To examine patterns of change in assemblage composition, the excavated deposit was divided into a series of analytical units (AUs). When deciding how to divide an excavation into appropriate AUs, there is no comprehensive rule; they are designed to suit particular research questions (Allen 1996b:158). In the case of Square I5 stratigraphic units (SUs) are used as the basis for AUs. Using SUs as analytical units aims to avoid arbitrary grouping of noncontemporaneous materials, grouping them instead into assumed depositional units. The relationship of SUs to AUs is shown in Table 6. SU1b is not included in the analytical units. As mentioned earlier, it is likely to be the result of disturbance. SU2 and SU3 have been combined as they appear to be contemporaneous. As Figure 7 shows, SU3 envelops SU2, with deposits of the former occurring both above and below deposits of the latter. The time-span of each AU has been calculated using the values determined by the linear regression (Table 6).

AU1 is the surface layer. It contains an extremely small number of artefacts and other cultural materials compared with the other AUs. The low number of artefacts may result from sampling bias produced by disturbance or removal of artefacts by recent visitors to the site or simply the result of a reduction in deposition of cultural material related to disruptions in traditional Aboriginal lifeways in the region. For these reasons, AU1 may not be useful for statistical analysis, although its raw data will be given, for the record. 
Table 6. Relationship between analytical units (AUs) and stratigraphic units (SUs) for Square I5, showing the estimated time-span of each $\mathrm{AU}$.

\begin{tabular}{|c|c|c|r|}
\hline AU & SU & Range (cal BP) & Total Years \\
\hline 1 & $1 \mathrm{a}, 1 \mathrm{~b}$ & Present-276 & 276 \\
\hline 2 & 2,3 & $276-3173$ & 2897 \\
\hline 3 & 4 & $3173-4395$ & 1498 \\
\hline 4 & 5 & $4395-7890$ & 3495 \\
\hline
\end{tabular}

Another potential problem with the AUs is the variable length of time represented by each unit. Grouping archaeological remains deposited over several thousand years involves the homogenisation of evidence and any behavioural conclusions drawn from it must be at a coarse level. Nonetheless, large analytical units still have the potential to "separate ranges of the total sets of behaviour reflected archaeologically within them" (Allen 1996a:120). Differences between these ranges of behaviour can provide evidence for culture change.

\section{Results of Analysis \\ Stone Artefacts}

As noted earlier, stone artefacts retrieved from Big Foot Art Site have the potential to provide a useful comparison with sequences in adjacent regions, and especially Mulvaney's model for Australian tool assemblages, based on his work in the Central Queensland Highlands (Mulvaney and Joyce 1965). Mulvaney documented significant mid-to-late
Holocene shifts in numbers of stone artefacts deposited, as well as changes in artefact size and choice of raw materials. For the purposes of the present study, stone artefact analyses sought to determine if such changes were represented in the Big Foot Art Site assemblage.

\section{Artefact Discard Rate}

Stone artefacts were counted and calculated as numbers per AU. During excavation and the initial sorting of material from the site, both the excavators and sorters observed an increase, then decrease, with depth in the number of artefacts from Square I5. However, the AUs are of varying sizes, so the raw data have little meaning until they are related to temporal units. To check for non-random, temporal variations in artefact quantity, artefact discard rates were calculated as the number of artefacts discarded per 100 years.

Figure 9 shows that the artefact discard rate peaks in AU3. During the earliest period of occupation, c.7,900 cal BP to c. 4,400 cal BP, artefacts are deposited at a rate of $34.4 / 100$ years. This rate nearly doubles to $65.8 / 100$ years during the period c. 4,400 cal BP to c.3,200 cal BP and then drops to $19.9 / 100$ years between c.3,200 cal BP and c.300 cal BP.

A chi-square test shows that the different rate of artefact discard during the period 4,400-3,200 cal BP is statistically significant, bearing out the observations of the excavators during fieldwork, and echoing increases in artefact discard rates identified in the Central Queensland Highlands (Mulvaney and Joyce 1965).

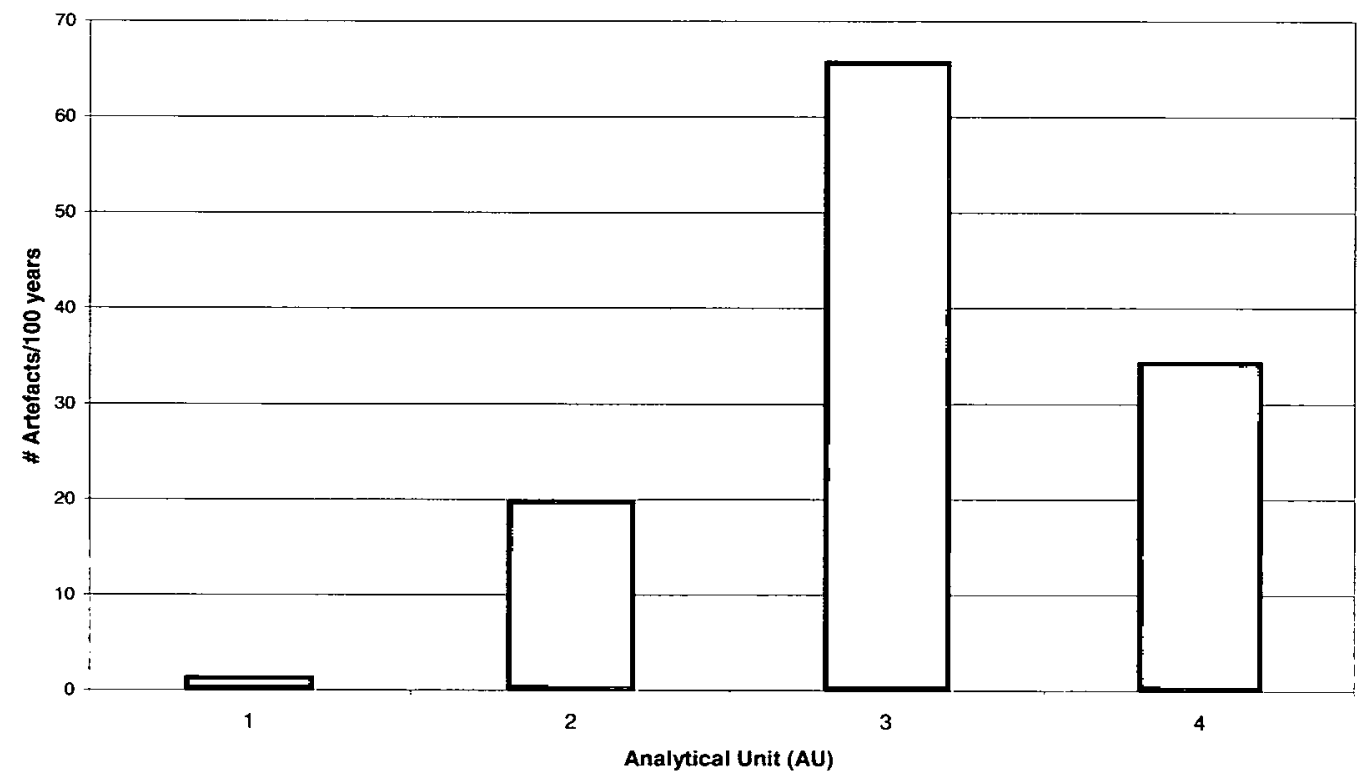

Figure 9. Artefact discard rate per 100 years, Square 15. 


\section{Artefact Classes}

In this analysis, artefacts were classified as either flakes, broken flakes, flaked pieces or cores, following categories used by Hiscock (1988:362), Hiscock and Hall (1988:63-64) and Sullivan and Rosen (1985:759). Flakes were defined as pieces of rock struck from a core, and exhibiting either a ringcrack, a point of force application, a bulb of percussion, an eraillure scar, or any combination of these attributes. Broken flakes are flakes that have been broken during or after production either by transverse or longitudinal snapping. Flaked pieces are artefacts which cannot be classified as a flake, core or broken flake owing to the absence of defining attributes. Cores are defined as pieces of stone with one or more negative flake scars but no positive flake scars.

The numbers of artefacts in each class are shown in Table 7. Three cores are present, one in AU2 and two in AU3. There is a consistent increase in the numbers in each artefact class with depth, from AU2 to AU4.

\section{Size of Artefacts}

The maximum dimension of each artefact was measured with callipers and its weight with an electronic balance. The size of all artefacts was recorded as average maximum dimensions in millimetres and to the nearest tenth of a gram in weight, per AU (Table 8).

A pattern of very little temporal change in artefact size emerges. In AUs 2-4, the greatest difference in average weight is only $0.07 \mathrm{~g}$ and the greatest difference in average maximum dimension only $0.23 \mathrm{~mm}$. The ranges of weights and maximum dimensions are also very similar for these three AUs.

The category of flakes was tested separately for size, measured by maximum dimension (Table 8). The average maximum dimension of whole flakes reflects the pattern of maximum dimensions for all artefacts. Chi-square tests on weight and maximum dimension show that there is no statistically significant change in these characteristics either for flakes alone or for all artefacts in AUs 2-4.

\section{Technological Tests}

Further technological analysis was conducted to examine the nature of the stone assemblage and to establish whether the observed variation in the artefact discard rate was associated with a corresponding change in manufacturing behaviour. Technological attributes that may explain the apparent variation in numbers of deposited artefacts were selected. There are several changes in technology which could produce more flakes from each core knapped. The changes tested for Square I5 are raw materials, core reduction strategies, the use of excessive force, varying stages of reduction being carried out at the site and the use of thermal pretreatment (Table 9). Changes to one or a combination of these factors could account for variation in the artefact discard rate if the differences were statistically significant and synchronous with variations in discard rate. The technological variables that could have contributed to depositional variation at Big Foot Art Site and the indicators of such technology are listed in Table 9. The last two tests are not necessarily aspects of technology, but are relevant in that their presence may explain increases in total artefact numbers as well as being circumstantial indicators of increases in site use.

\section{Raw Materials}

The identified raw materials are quartz, basalt, greywacke, rhyolite, jasper, quartzite, chert, hematite, siltstone and silicified wood. Some raw materials were difficult to identify with certainty, owing to small artefact size or the extent of weathering, and have been classified as 'unidentified'. The data for raw materials are shown in Table 10 as numbers and as percentages of the total artefacts in each AU.

A wide variety of raw materials are represented in all levels. The deposition rate of quartz remains constant throughout the excavation, comprising about one-third of the artefacts in each of AUs 2-4. Basalt is the next most common material in AUs 2-3, but its frequency decreases in AU4. Rhyolite and quartzite show the reverse trend, being more common in AU4 than AUs 2-3. There is no marked introduction of new materials and no loss of a material once introduced. It is true that silicified wood appears only in AU4, but it is only a very small component and does not constitute a major change in overall trends. Throughout, quartz, basalt and quartzite are the main materials used, with varying amounts of other stone. A chi-square test shows that there is a statistically significant temporal change in raw materials. Basalt and quartzite are the major contributors to the statistically significant results, with changes as described above.

Although the increase in jasper also contributes to the statistical significance of the change, it comprises only 76 of the total 2,767 artefacts, and thus must be viewed as a minor factor. Rhyolite too decreases markedly through time. However, it comprises 197 artefacts, or only about $7 \%$ of the total number, therefore the decrease in rhyolite is also only a minor factor. 
The most important trends, then, in terms of statistical significance and numbers in the stone assemblage are:

- a steady use of quartz through all levels of the excavation; and,

- an increase in basalt through time at the expense of quartzite.

None of the identified trends in raw material use match the pattern of change in artefact discard rates. Thus, although the changes may be worth investigating further for their own sake, the changes in stone types do not appear to be directly related to the change in the artefact discard rate.

There is no evidence for platform faceting or outrepassé terminations in the stone artefact assemblage. The cases of bipolar flaking, variation in core rotations, distally-oriented scars on flakes, variation in the cortex present on flakes, thermal pretreatment of artefacts, transverse snaps of flakes and indications of uncontrolled heating are very few, and the changes in these attributes between AUs are not statistically significant (see Westcott 1997 for full details).

There is a high number of flakes showing overhang removal and crushed platforms, indicating a change in platform preparation and in the amount of force being used (Table 11). The increase in crushed platforms is not coincident with the timing of the increase in artefact deposition. Only the increase in overhang removal mirrors the discard rate, but, along with all the other tests for change in technology, there is no statistically significant increase during the period between 3,200 cal BP to $4,400 \mathrm{cal} \mathrm{BP}$. Thus, there is no convincing evidence in the analysed sample for a change in technology during any period represented in this excavation. Given these results, there is no evidence at present in keeping with the hypothesis that a change in technology created or contributed to the observed variations in artefact discard rates.

Table 7. Occurrence of artefact classes, Square I5.

\begin{tabular}{|c|r|r|r|r|r|r|r|r|r|}
\hline AU & \multicolumn{2}{|c|}{ Flakes } & \multicolumn{2}{c|}{$\begin{array}{c}\text { Broken } \\
\text { Flakes }\end{array}$} & \multicolumn{2}{c|}{$\begin{array}{c}\text { Flaked } \\
\text { Pieces }\end{array}$} & \multicolumn{2}{c|}{ Cores } & \multicolumn{1}{c|}{$\begin{array}{c}\text { Total } \\
\text { Artefacts }\end{array}$} \\
\hline & \multicolumn{1}{|c|}{$\#$} & \multicolumn{1}{c|}{$\%$} & \multicolumn{1}{c|}{$\#$} & \multicolumn{1}{c|}{$\%$} & \multicolumn{1}{c|}{$\#$} & \multicolumn{1}{c|}{$\%$} & $\#$ & \multicolumn{1}{c|}{$\%$} & \multicolumn{1}{c|}{$\#$} \\
\hline 1 & 1 & 25.0 & 0 & 0 & 3 & 75.0 & 0 & 0 & 4 \\
\hline 2 & 93 & 16.2 & 31 & 5.4 & 451 & 78.3 & 1 & 0.2 & 576 \\
\hline 3 & 126 & 12.8 & 58 & 5.9 & 800 & 81.1 & 2 & 0.2 & 986 \\
\hline 4 & 177 & 14.7 & 83 & 6.9 & 941 & 78.4 & 0 & 0 & 1201 \\
\hline Total & 397 & 14.4 & 172 & 6.2 & 2195 & 79.3 & 3 & 0.1 & 2767 \\
\hline
\end{tabular}

Table 8. Artefact size by weight and maximum dimension, Square I5.

\begin{tabular}{|c|c|c|c|r|r|}
\hline AU & $\begin{array}{c}\text { Weight } \\
\text { Range } \\
(\mathbf{g})\end{array}$ & $\begin{array}{c}\text { Average } \\
\text { Weight } \\
(\mathbf{g})\end{array}$ & $\begin{array}{c}\text { Range of Max. } \\
\text { Dimensions } \\
(\mathbf{m m})\end{array}$ & $\begin{array}{c}\text { Average Max. } \\
\text { Dimension } \\
(\mathbf{m m})\end{array}$ & $\begin{array}{c}\text { Average Max. } \\
\text { Dimension } \\
\text { Flakes Only (mm) }\end{array}$ \\
\hline 1 & $<0.1-0.1$ & 0.05 & $7-8$ & 7.30 & 7.0 \\
\hline 2 & $<0.1-9.7$ & 0.23 & $3-35$ & 7.52 & 8.7 \\
\hline 3 & $<0.1-11.8$ & 0.16 & $3-40$ & 7.75 & 10.2 \\
\hline 4 & $<0.1-9.5$ & 0.19 & $3-39$ & 7.70 & 9.3 \\
\hline
\end{tabular}


Table 9. Tests of technological strategies that may increase artefact discard rates.

\begin{tabular}{|l|l|}
\hline Aspect of Technology & Test Indicators \\
\hline Raw Material Use & Raw material type \\
\hline Use of Excessive Force & Crushed platforms \\
\hline Stage of Reduction & Presence of cortex \\
\hline Thermal Pre-treatment & Surface lustre \\
\hline Uncontrolled Heating & Crenated fractures \\
\hline Post-Depositional Breakage & Transverse snapping \\
\hline
\end{tabular}

Table 10. Occurrence of raw materials, Square I5.

\begin{tabular}{|c|c|c|c|c|c|c|c|c|}
\hline \multirow[b]{2}{*}{ Raw Material } & \multicolumn{2}{|c|}{ AU1 } & \multicolumn{2}{|c|}{ AU2 } & \multicolumn{2}{|c|}{ AU3 } & \multicolumn{2}{|c|}{ AU4 } \\
\hline & $\#$ & $\%$ & $\#$ & $\%$ & $\#$ & $\%$ & \# & $\%$ \\
\hline Quartz & 0 & 0 & 198 & 34.4 & 355 & 36.0 & 438 & 36.5 \\
\hline Basalt & 2 & 50.0 & 142 & 24.7 & 246 & 24.9 & 192 & 15.9 \\
\hline Greywacke & 0 & 0 & 19 & 3.3 & 40 & 4.1 & 27 & 2.3 \\
\hline Rhyolite & 2 & 50.0 & 25 & 4.3 & 65 & 6.5 & 105 & 8.7 \\
\hline Jasper & 0 & 0 & 30 & 5.2 & 33 & 3.4 & 13 & 1.1 \\
\hline Quartzite & 0 & 0 & 77 & 13.4 & 129 & 13.1 & 233 & 19.4 \\
\hline Chert & 0 & 0 & 31 & 5.4 & 47 & 4.8 & 63 & 5.3 \\
\hline Hematite & 0 & 0 & 5 & 0.9 & 0 & 0 & 1 & 0.1 \\
\hline Siltstone & 0 & 0 & 23 & 3.9 & 22 & 2.2 & 51 & 4.2 \\
\hline Silicified Wood & 0 & 0 & 0 & 0 & 0 & 0 & 7 & 0.6 \\
\hline Unidentified & 0 & 0 & 26 & 4.5 & 49 & 5.0 & 71 & 5.9 \\
\hline Total & 4 & 100 & 576 & 100 & 986 & 100 & 1201 & 100 \\
\hline
\end{tabular}

Table 11. Number of flakes exhibiting overhang removal and crushed platforms, Square I5.

\begin{tabular}{|c|c|c|r|r|r|r|}
\hline & \multicolumn{2}{|c|}{ Overhang Removal } & \multicolumn{3}{c|}{ Crushed Platforms } \\
\hline AU & $\#$ & $\begin{array}{c}\text { Whole \& } \\
\text { Broken } \\
\text { Flakes }\end{array}$ & $\%$ & $\#$ & $\begin{array}{l}\text { Whole } \\
\text { Flakes }\end{array}$ & $\%$ \\
\hline 1 & 0 & 1 & 0 & 0 & 1 & 0 \\
\hline 2 & 9 & 124 & 7 & 6 & 93 & 7 \\
\hline 3 & 21 & 184 & 11 & 8 & 126 & 6 \\
\hline 4 & 19 & 260 & 7 & 6 & 177 & 3 \\
\hline Total & 49 & 569 & 25 & 20 & 397 & 16 \\
\hline
\end{tabular}




\section{Discussion}

The Central Queensland Highlands provide a major body of comparative data for the general Central Queensland region. The excavated sample from Big Foot Art Site is currently the only assemblage subjected to detailed technological analysis for the Burnett-Curtis region. Preliminary assessment of trends in the Big Foot Art Site assemblage therefore provide a framework for on-going research, aiming in part to test the wider applicability of models developed for the Central Queensland Highlands. It is stressed that the conclusions drawn here are preliminary and open to modification, pending further investigation.

\section{Increased Artefact Discard Rate}

Big Foot Art Site was first occupied during a period when only four of the 11 excavated Central Highlands sites were being used. Both Big Foot Art Site and the four Highlands sites begin with relatively low rates of stone artefact discard. The increase in the rate of artefact discard at Big Foot Art Site occurs at about the same time (c.4,400 cal BP) as the onset of the Small Tool Tradition (from c. 4,500 cal BP) and more intense occupation (from c. 4,300 cal BP) in the Central Queensland Highlands. The pattern described here is also mirrored in the nearby Roof Fall Cave assemblage (see Eales et al. this volume). The number of dated rockshelter sites in the Highlands increase at this time, as do the numbers of tools discarded per temporal unit (Morwood 1984). Thus there is a trend of increasing numbers of artefacts during the mid-Holocene common to both areas.

A mid-Holocene increase in the number of dated sites and artefact discard rates has been described in many areas of Australia, including two other regions in Queensland, namely southeast Cape York Peninsula (David and Chant 1995; Morwood and Hobbs 1995) and southeast Queensland (Hiscock and Hall 1988; Ulm and Hall 1996). The similarity tentatively identified here, between Cania Gorge and the Central Queensland Highlands, may therefore be part of a much wider trend.

\section{Decreased Artefact Discard Rate}

The subsequent decrease in stone artefact discard rates at Big Foot Art Site after c.3,200 cal BP mirrors trends identified both in Roof Fall Cave and in the Central Queensland Highlands. In the Highlands, Morwood (1981:42) argues that the decreases coincide with the advent of the Recent Tradition, c. 2,000 BP. Decreases in cultural materials are also reported in some of the rockshelters in the hinterland of the Moreton region in southeast Queensland, but occur much later in the Holocene (c.2,000-1,000 BP) (Hall and Hiscock 1988; Morwood 1986, 1987).

\section{Tool Types}

While the increase in discard rates at Big Foot Art Site matches those in sites in the Central Queensland Highlands and elsewhere, Big Foot has not yielded any formal tool types to compare with the stone industries identified in the Highlands. At the time of transition between these industries in the Highlands, the artefact sample from Big Foot Art Site does not show a change in the aspects of technology so far tested, nor a corresponding decrease in artefact size. There is an increase in the use of basalt from 4,400 cal BP and Mulvaney (Mulvaney and Joyce 1965:171) found small amounts of basalt in the top $30 \mathrm{~cm}$ of deposits at Kenniff Cave. However, this change is not a major trend and the predominant stone maintained its status: quartzite at Kenniff Cave, and quartz at Big Foot Art Site. At present it seems sensible to suggest that the dissimilarities between changing typology in the Central Queensland Highlands and unchanging technology at Big Foot Art Site may simply result from sampling bias, as the analysed sample from Big Foot is very small, both in absolute terms, as well as in comparison to the samples available from the Central Queensland Highlands. Until analytical results are available for Squares G6 and G7 and other Cania sites such as Roof Fall Cave and Grinding Groove Cave, spatial variation in discard patterns of materials within the shelter cannot be discounted as a cause of the apparent variations in stone artefact discard rates.

\section{Conclusion}

Square I5 of Big Foot Art Site has cultural deposits indicating a low level of occupation from c.8,000 cal BP, with a period of increased stone artefact deposition, perhaps indicating more intensive use, between 4,400- 3,200 cal BP. There is as yet no evidence for a change in stone artefact manufacture or a trend away from use of local stone at any stage during the period of occupation.

If Big Foot Art Site's artefact discard rate is related to more intense site use, it occurred during a time when the Central Queensland Highlands also demonstrates a sudden increase in regional occupational levels and rates of site use. This is also true of southeast Cape York Peninsula, but pre-dates similar changes in southeast Queensland by approximately 3,000 years. Perhaps Big Foot Art Site was visited by small groups during the mid-Holocene and was used only for tool maintenance and/or artrelated activities which did not leave archaeological 
signatures related to wider patterns of behavioural change. On the other hand, the patterns of variation in stone artefact discard rates may be part of a much wider pattern of regionalization, proposed not only for the Central Queensland Highlands (Morwood 1984), but for much of Australia (Lourandos 1997).

\section{Acknowledgements}

Fieldwork and radiocarbon dates were funded by the National Estate Grants Program. Thanks are due to the numerous field assistants who worked on the excavations of Big Foot - Kate Quirk, Nathan Woolford, Nicola Bristed, Paul McInnes and Nick Culbert. John Richter drew Figure 1. Dr Andrew Simpson and Dr Rod Holcombe (both of the Department of Earth Sciences, University of Queensland) assisted with identification of raw materials. Denis Dray and Neil Teague (Queensland National Parks and Wildlife Service) provided advice and assistance in the field. Jon Prangnell (University of Queenslanđ Archaeological Services Unit) advised on the use of statistics. Tony Eales (Aboriginal and Torres Strait Islander Studies Unit, University of Queensland) checked data tables and commented on several drafts.

\section{References}

Allen, J. 1996a Bone Cave. In J. Allen (ed.), Report of the Southern Forests Archaeological Project: Site Descriptions, Stratigraphies and Chronologies, pp.91122. Vol. 1. Bundoora: Archaeology Publications, School of Archaeology, La Trobe University.

Allen, J. 1996b Warreen Cave. In J. Allen (ed.), Report of the Southern Forests Archaeological Project: Site Descriptions, Stratigraphies and Chronologies, pp.136167. Vol. 1. Bundoora: Archaeology Publications, School of Archaeology, La Trobe University.

David, B. and D. Chant 1995 Rock art and regionalisation in north Queensland prehistory. Memoirs of the Queensland Museum 37(2):357-528.

Eales, T., C. Westcott, I. Lilley, S. Ulm, D. Brian and C. Clarkson this volume Roof Fall Cave, Cania Gorge: Site report. Queensland Archaeological Research 11.

Hall, J. and P. Hiscock 1988 The Moreton Region Archaeological Project (MRAP)-Stage II: An outline of objectives and methods. QueenslandArchaeological Research 5:4-24.

Hiscock, P.D. 1988 Prehistoric Settlement Patterns and Artefact Manufacture at Lawn Hill, Northwest Queensland. Unpublished PhD thesis, Department of Anthropology and Sociology, University of Queensland, Brisbane.

Hiscock, P. and J. Hall 1988 Technological change at Bushranger's Cave (LA:A11) S.E. Queensland. Queensland Archaeological Research 5:63-89.
Lilley, I., D. Brian, C. Clarkson and S. Ulm 1998 Pleistocene Aboriginal occupation at Cania Gorge, Central Queensland: Preliminary results of fieldwork and implications. Archaeology in Oceania 33(1):28-31.

Lilley, I. and S. Ulm 1995 The Gooreng Gooreng Cultural Heritage Project: Some proposed directions and preliminary results of the archaeological program. Australian Archaeology 41:11-15.

Lilley, I. and S. Ulm this volume The Gooreng Gooreng Cultural Heritage Project: Preliminary results of archaeological research, 1993-1997. Queensland Archaeological Research 11.

Lourandos, H. 1997 Continent of Hunter-Gatherers: New Perspectives in Australian Prehistory. Cambridge: Cambridge University Press.

Morwood, M.J. 1981 Archaeology of the Central Queensland Highlands: The stone component. Archaeology in Oceania 16(1):1-52.

Morwood, M.J. 1984 The prehistory of the Central Queensland Highlands. Advances in World Archaeology 3:325-379.

Morwood, M. 1987 The archaeology of social complexity in south-east Queensland. Proceedings of the Prehistoric Society 53: 337-350.

Morwood, M.J. and D.R. Hobbs 1995 Themes in the prehistory of tropical Australia. Antiquity 69:747-768.

Mulvaney, D.J. 1975 The Prehistory of Australia. Rev. ed. Melbourne: Penguin.

Mulvaney, D.J. and E.B. Joyce 1965 Archaeological and geomorphological investigations on Mt. Moffatt station, Queensland, Australia. Proceedings of the Prehistoric Society 31:147-212.

Stuiver, M. and G.W. Pearson 1993 High-precision bidecadal calibration of the radiocarbon time scale, AD 1950-500 BC and 2500-6000 BC. Radiocarbon 35(1):1-23.

Stuiver, M. and P.J. Reimer 1993 Extended ${ }^{14} \mathrm{C}$ data base and revised CALIB $3.0{ }^{14} \mathrm{C}$ age calibration program. Radiocarbon 35(1):215-230.

Sullivan, P.S. and K.C. Rozen 1985 Debitage analysis and archaeological interpretation. American Antiquity 50:755-779

Ulm, S. and J. Hall 1996 Radiocarbon and Cultural Chronologies in Southeast Queensland Prehistory. In S. Ulm, I. Lilley and A. Ross (eds), Australian Archaeology '95: Proceedings of the 1995 Australian Archaeological Association Annual Conference, pp.4562. Tempus 6. St Lucia: Anthropology Museum, Department of Anthropology and Sociology, University of Queensland.

Westcott, C. 1997 A Technological Analysis of the Stone Artefacts From Big Foot Art Site, Cania Gorge. Unpublished B.A. (Hons) thesis, Department of Anthropology and Sociology, University of Queensland, Brisbane. 
Appendix A. Big Foot Art Site, Square 15, Excavation Data and Dominant Materials.

\begin{tabular}{|c|c|c|c|c|c|c|c|c|c|c|}
\hline $\mathbf{X U}$ & $\begin{array}{l}\text { Total } \\
\text { Weight } \\
\text { (g) }\end{array}$ & $\begin{array}{c}\text { Artefactual } \\
\text { Stone } \\
\text { (g) }\end{array}$ & $\begin{array}{l}\text { Non- } \\
\text { Artefactual } \\
\text { Stone } \\
\text { (g) }\end{array}$ & $\begin{array}{c}\text { Charcoal } \\
\text { (g) }\end{array}$ & $\begin{array}{c}\text { Bone } \\
\text { (g) }\end{array}$ & $\begin{array}{c}\text { Organic } \\
\text { Material } \\
\text { (g) }\end{array}$ & $\begin{array}{c}\text { Insect } \\
\text { Remains } \\
\text { (g) }\end{array}$ & $\begin{array}{l}\text { Soil } \\
(\mathrm{g})\end{array}$ & $\begin{array}{l}\text { Shell } \\
\text { (g) }\end{array}$ & $\begin{array}{c}\text { Ochre } \\
\text { (g) }\end{array}$ \\
\hline 1 & 9.0 & 0.2 & 359.6 & 13.2 & 0.5 & 227.9 & 1.6 & 3.6 & $>0.1$ & 0 \\
\hline 2 & 7.0 & 0.7 & 327.5 & 39.9 & 1.5 & 6.7 & 0.1 & 6.6 & $>0.1$ & 0 \\
\hline 3 & 4.5 & 0.4 & 183.3 & 31.7 & 0.4 & 3.7 & 0.1 & 5.5 & 0 & 0 \\
\hline $4 a$ & 6.8 & 10.6 & 427.3 & 40.7 & 2.4 & 4.3 & 0.1 & 12.0 & $>0.1$ & 0 \\
\hline $4 b$ & 0.5 & 0 & 79.3 & 2.6 & 0 & 0.7 & 0 & 3.2 & 0 & 0 \\
\hline 5 & 3.3 & 2.6 & 170.4 & 19.1 & 1.3 & 1.9 & 0 & 0 & 0.1 & 0.5 \\
\hline $6 a$ & 4.6 & 0.6 & 220.7 & 0.1 & 2.3 & 1.9 & 0 & 1.6 & 0.1 & 0 \\
\hline $6 \mathrm{~b}$ & 1.5 & 0.8 & 75.1 & 2.5 & 0.6 & 1.2 & 0 & 1.0 & 0.4 & 0.1 \\
\hline 7 & 3.0 & 3.9 & 274.7 & 16.3 & 0.4 & 0.7 & 0 & 1.6 & 0 & 0.1 \\
\hline 8 & 3.5 & 2.4 & 347.3 & 8.7 & 1.1 & 2.5 & 0 & 3.0 & 0 & 0.8 \\
\hline 9 & 0.8 & 0.1 & 43.9 & 1.1 & 0.2 & $>0.1$ & 0 & 1.1 & 0 & 0.1 \\
\hline 10 & 2.0 & 0.7 & 102.9 & 12.3 & 0.9 & 0.5 & 0 & 0.2 & 0 & 0.2 \\
\hline $11 \mathrm{a}$ & 4.5 & 1.5 & 349.6 & 18.7 & 2.7 & 2.2 & 0 & 4.6 & 0 & 0.4 \\
\hline $11 b$ & 1.5 & 0.2 & 83.2 & 1.4 & 0.5 & $>0.1$ & 0 & 0.1 & 0 & 0.3 \\
\hline $12 \mathrm{a}$ & 1.5 & 4.5 & 110.9 & 3.2 & 0.8 & 1.2 & 0 & 0.6 & 0 & 0.6 \\
\hline $12 b$ & 2.5 & 0.4 & 152.4 & 3.4 & 1.2 & 0.7 & 0 & 0.1 & 0 & 0.6 \\
\hline $13 a$ & 3.5 & 0.9 & 203.6 & 17.1 & 4.4 & 8.2 & 0 & 1.1 & 0 & 1.2 \\
\hline $13 \mathrm{~B}(1)$ & 4.5 & 3.3 & 383.5 & 11.9 & 2.3 & 5.3 & 0 & 1.0 & 0 & 2.1 \\
\hline $13 \mathrm{~B}(2)$ & 3.0 & 2.2 & 242.0 & 9.5 & 2.0 & 2.9 & 0 & 1.0 & 0 & 0.3 \\
\hline $14 \mathrm{a}$ & 7.0 & 8.3 & 522.1 & 24.3 & 5.0 & 1.2 & 0 & 1.0 & 0 & 3.6 \\
\hline $14 b$ & 6.5 & 6.4 & 492.1 & 19.1 & 6.1 & 3.2 & 0 & 0.9 & 0 & 5.3 \\
\hline $15 \mathrm{a}$ & 4.5 & 4.2 & 297.2 & 8.6 & 4.5 & 0.8 & 0 & 2.6 & 0 & 3.4 \\
\hline $15 b$ & 7.0 & 11.6 & 502.1 & 16.6 & 5.4 & 2.9 & $>0.1$ & 0.6 & 0 & 6.5 \\
\hline $16 \mathrm{a}$ & 2.0 & 13.2 & 118.6 & 3.4 & 1.3 & 0.1 & $>0.1$ & 0.5 & 0 & 2.8 \\
\hline $16 \mathrm{~b}$ & 5.5 & 23 & 403.8 & 11.3 & 8.9 & 1.8 & $>0.1$ & 1.4 & 0 & 4.6 \\
\hline $17 \mathrm{a}$ & 3.3 & 12.3 & 321.2 & 5.2 & 6.2 & 2.0 & 0.1 & 3.2 & 0 & 0.7 \\
\hline $17 \mathrm{~b}$ & 7.0 & 55.6 & 504.8 & 9.0 & 9.8 & 2.7 & $>0.1$ & 2.0 & 0 & 7.1 \\
\hline $18 \mathrm{a}$ & 3.2 & 74.5 & 179.8 & 3.7 & 3.2 & 0.3 & $>0.1$ & 0.8 & 0 & 1.1 \\
\hline $18 b$ & 7.0 & 39.5 & 467.9 & 6.5 & 11.0 & 8.9 & 0.2 & 0 & 0 & 5.7 \\
\hline $19 a$ & 2.0 & 3.3 & 132.4 & 7.9 & 2.9 & 0.2 & 0.3 & 0.3 & 0 & 1.1 \\
\hline $19 b$ & 8.0 & 63.2 & 488.3 & 7.5 & 5.9 & 12.0 & 0 & 0 & 0 & 0.8 \\
\hline $20 a$ & 1.5 & 2.5 & 95.5 & 4.6 & 0.1 & $>0.1$ & 0 & 0.4 & 0 & 0.2 \\
\hline
\end{tabular}


Appendix A. Big Foot Art Site, Square I5, Excavation Data and Dominant Materials (continued).

\begin{tabular}{|c|c|c|c|c|c|c|c|c|c|c|}
\hline $\mathbf{X U}$ & $\begin{array}{c}\text { Total } \\
\text { Weight } \\
\text { (g) }\end{array}$ & $\begin{array}{l}\text { Artefactual } \\
\text { Stone } \\
\text { (g) }\end{array}$ & $\begin{array}{l}\text { Non- } \\
\text { Artefactual } \\
\text { Stone } \\
\text { (g) }\end{array}$ & $\begin{array}{c}\text { Charcoal } \\
\text { (g) }\end{array}$ & $\begin{array}{c}\text { Bone } \\
(\mathrm{g})\end{array}$ & $\begin{array}{c}\text { Organic } \\
\text { Material } \\
\quad \text { (g) }\end{array}$ & $\begin{array}{c}\text { Insect } \\
\text { Remains } \\
\text { (g) }\end{array}$ & $\begin{array}{c}\text { Soil } \\
(\mathrm{g})\end{array}$ & $\begin{array}{c}\text { Shell } \\
\text { (g) }\end{array}$ & $\begin{array}{c}\text { Ochre } \\
\text { (g) }\end{array}$ \\
\hline $20 \mathrm{~b}$ & 7.0 & 23.9 & 441.5 & 0 & 2.8 & 1.2 & 0 & 0 & 0 & 0.2 \\
\hline 21 & 10.0 & 101.2 & 589.6 & 21.0 & 1.2 & 1.8 & 0.1 & 0 & 0 & 4.7 \\
\hline $22 \mathrm{a}$ & 1.0 & 1.1 & 79.4 & 5.6 & 0.3 & 13.2 & 0 & 0 & 0 & 0.4 \\
\hline $22 b$ & 6.5 & 44.3 & 394.9 & 14.3 & 0.9 & 0.8 & 0.1 & 3.6 & 0 & 0.6 \\
\hline 23 & 9.5 & 23.1 & 714.1 & 32.2 & 0.3 & 25.8 & 0.2 & 5.5 & 0 & 5.2 \\
\hline 24 & 7.0 & 21.7 & 526.7 & 22.6 & 0.5 & 0.5 & 0.2 & 0.6 & 0 & 0 \\
\hline 25 & 7.5 & 26.1 & 580.8 & 35.6 & 0.6 & 0.3 & 0 & 0 & 0 & 0 \\
\hline 26 & 5.0 & 8.1 & 351.6 & 30.7 & 0.2 & 0.9 & 0 & 0 & 0 & 0 \\
\hline 27 & 5.0 & $10: 8$ & 510.4 & 27.5 & 0.2 & 0.2 & 0 & 0.8 & 0 & 1.6 \\
\hline 28 & 4.5 & 2.0 & 347.3 & 24.7 & 0 & 0.4 & 0 & 0.1 & 0 & 2.4 \\
\hline 29 & 2.5 & 0.5 & 150.0 & 17.0 & 0.2 & 0.3 & 0 & 0 & 0 & 0.3 \\
\hline 30 & 5.0 & 0.6 & 432.4 & 30.1 & 0.1 & 0.4 & 0 & 0 & 0 & 0.5 \\
\hline 31 & 3.0 & 3.7 & 281.2 & 12.5 & 0 & 0.5 & 0.2 & 0 & 0 & 0.3 \\
\hline 32 & 4.0 & 15.5 & 359.8 & 22.1 & 0 & 0.3 & 0 & 0 & 0.1 & 0.7 \\
\hline 33 & 4.5 & 5.1 & 377.3 & 21.2 & 0.3 & 0.2 & 0 & 0.1 & 0 & 0.4 \\
\hline 34 & 2.5 & 3.3 & 245.7 & 19.3 & 0 & 0.1 & 0 & 0 & 0 & 0 \\
\hline 35 & 2.0 & 0.5 & 329.6 & 16.3 & 0 & 0.1 & 0 & 0 & 0 & 0 \\
\hline 36 & 4.5 & 3.4 & 489.2 & 9.3 & 0 & 3.0 & 0 & 0.4 & 0 & 0 \\
\hline 37 & 2.0 & 0.5 & 325.1 & 11.6 & 0 & 0.9 & 0 & 0 & 0 & 0 \\
\hline 38 & 2.5 & 0.9 & 249.6 & 9.3 & 0 & 3.6 & 0 & 1.3 & 0 & 0 \\
\hline
\end{tabular}

